\title{
Holistic Approach to Axonal Regeneration in Cases of Spinal Cord Injury
}

\section{Da-Chuan Yeh}

Division of Infectious Diseases, Buddhist Tzu Chi General Hospital, Hualien, Taiwan

\begin{abstract}
Spinal Cord Injuries (SCls) that result from trauma can cause the death of nerve cells and lead to distal neuronal death. The hostility of the lesion microenvironment imposes multiple conditions that must be met to achieve functional recovery. Considerable research indicated interactions and signaling, such as supporting cells, extracellular matrix, neurotrophic factors and biodegradable polymers for axonal regeneration. In recent years, researchers have been seeking novel biomaterials that are capable of stimulating cellular regeneration and promoting functional recovery. The ability of various biomaterials to create bridging structures and facilitate axonal growth has also been investigated. In this manuscript, we outline the progress researchers have made in developing holistic approaches to axonal regeneration in cases of spinal cord injury. We report on a number of therapeutic methods that could be used to promote neurological recovery and examine their clinical applicability. We also share a number of recent insights that have enhanced the feasibility of multiple channel bridges in the treatment of SCl.
\end{abstract}

Keywords: Biomaterial scaffolds; Stem cells; Schwann cells; Neurotrophic factors; Extracellular Matrix; Axonal regeneration

\section{Introduction}

The neurological deficits imposed by spinal cord injury (SCI) can have long-term effects, and longitudinally oriented damage and/ or the impairment of neuronal cells can result in total paralysis [13]. Neuronal cell death is the primary pathogenetic mechanism in SCI; however, recent advances in stem cell therapy have increased the potential for such therapeutic techniques to benefit the replacement and regeneration of cells, the alleviation of degeneration symptoms, and the recovery of nerve function in the spinal cord [4-7]. Nonetheless, further development of stem cell therapy techniques has been hampered by logistical and ethical considerations [8-10], and the hostile microenvironment at the epicenter of the injury inhibits the survival, integration, and/or endogenous repair of transplanted cells $[11,12]$. These challenges have led researchers to adopt a holistic approach to the treatment of SCI - one that focus on altering the injury microenvironment in order to promote the survival and differentiation of transplanted cells [13-15]. This review provides a summary of multimodal interventions for the in situ alteration of the microenvironment in the treatment of SCI [7,16-20].

\section{Biomaterial Scaffolds}

Researchers have investigated the use of nerve guidance channels as biological scaffolds for axonal regeneration in SCI repair. These channels may be natural or synthetic and degradable or non-degradable [21-23]. They are meant to prevent the ingrowth of fibrous scar tissue, concentrate neurotrophic molecules released from damaged nerve stumps, and guide the growth of both proximal and distal nerve stumps [24]. Non-degradable channels comprise synthetic materials and provide a unified and controlled synthesis technology. Degradable channels preclude the need for permanent implantation of nondegradable material or the removal of non-degradable material via a second procedure. The natural materials used in degradable channels include collagen [25], alginate [26], hyaluronic acid [27], agarose [28], chitosan [29], fibrin [30], and methylcellulose [31], whereas the synthetic materials (polymers) used in non-degradable channels include poly(glycolic acid) (PGA) and copolymer poly(lactic-coglycolic acid) (PLGA), polycarbonate polymers, poly 2-hydroxyethyl methacrylate (PHEMA-co-MMA), poly(lactic acid) (PLA), poly- $\varepsilon$ - caprolactone (PCL), poly-N-(2-hydroxypropyl)-methacrylamide (PHPMA), poly(2-hydroxyethyl methacrylate) (PHEMA), degradable PLA-b-PHEMA copolymer, and self-assembling peptides (SAPs) [3235]. The criteria used to select biomaterials vary among remediation strategies; however, biocompatibility, mechanical strength, plasticity, and biodegradability are usually deemed essential. Researchers have considered the potential for neural stem cells and mesenchymal stem cells to benefit spinal cord regeneration based on observations that these stem cells are already seeded within the biomaterial scaffold [25,35-39]. Using these biomaterials as scaffolds has been shown to enhance the functional recovery of damaged spinal cords by prolonging stem cell survival through nutritional support or by directly replacing neurons and their supporting cells.

\section{Supporting Cells}

Numerous studies have investigated the efficacy of support cells, such as stem cells and Schwann cells, in the regenerative treatment of SCI [40-42]. Stem cells are characterized by self-renewal and the ability to differentiate into neuronal cells. This allows neural cells which were lost after SCI to be replaced [6,43-45]. Stem cells have also been attributed with neuroprotective and axon regenerationpromoting effects. Extensive research has supported the feasibility of treating spinal cord injuries using embryonic stem cells [46], neural stem cell-derived progenitor cells [47], mesenchymal stem cells [7], nasal olfactory mucosal cells [48], and neonatal astroglial cells [49]. The potential use of Schwann cells modified to release neurotrophic factors has also been studied [50], as Schwann cells play a crucial role in the endogenous repair of peripheral nerves and are able to dedifferentiate, migrate, proliferate, express growth promoting factors, and myelinate regenerating axons [41,50-52]. Nonetheless, the use of support cells

*Corresponding author: Da-Chuan Yeh, Division of Infectious Diseases Buddhist Tzu Chi General Hospital, Hualien, Taiwan, Tel: +886-3-8561825; E-mail: yehdandelion@gmail.com

Received January 06, 2018; Accepted January 15, 2018; Published January 22, 2018

Citation: Yeh DC (2018) Holistic Approach to Axonal Regeneration in Cases of Spinal Cord Injury. J Biomol Res Ther 7: 158. doi:10.4172/2167-7956.1000158

Copyright: (c) 2018 Yeh DC. This is an open-access article distributed under the terms of the Creative Commons Attribution License, which permits unrestricted use, distribution, and reproduction in any medium, provided the original author and source are credited. 
should be done in conjunction with other interventions in order to maximize axonal regeneration and functional recovery.

\section{Extracellular Matrix}

One approach that can be used to promote the repair of neurons and enhance neuronal plasticity in cases of SCI is the manipulation of the extracellular matrix (ECM) [53-56]. Changes in the composition and structure of ECM can contribute to the failure of regeneration [57]. Inflammation due to ECM disruption often leads to the release of hyaluronan fragments, tenascin, and sulfated proteoglycans. Thus, recovery from SCI is more likely to be achieved if the ECM environment is rendered more permissive through the manipulation of key components, such as inhibitory chondroitin sulphate proteoglycans, MMP, laminins, fibronectin, and collagen type IV $[58,59]$. Remodeling the ECM environment makes it possible to create a niche where the migration and proliferation of cells as well as the formation of nerve fascicle can be controlled. The in situ alteration of the ECM environment has also been shown to enhance the efficiency of cell transplantation methods [60,61]. Indeed, a clearly defined ECM environment helps to create a suitable niche for the regeneration of endogenous undifferentiated stem cells (including transplanted undifferentiated stem cells) [62], and stabilizing the ECM structure to reduce inflammation helps to create an environment conducive to tissue repair and the promotion of axonal plasticity following SCI $[20,54,55]$. In summary, microenvironment alteration can be used to control the fate of stem cells, prolong cell survival, facilitate neuroplasticity, and enhance differentiation into neuronal precursors. The current clinical applications of biomaterial scaffolds in SCI patients were summary in Table 1.

\section{Neurotrophic Factors}

Neurotrophic growth factors are central to the development and functional maintenance of the nervous system. They participate in neurogenesis, neuronal survival, axonal growth, synaptogenesis, and activity-dependent forms of synaptic plasticity [63-66]. Neuron survival and the regeneration of fiber tracts is aided by neurotrophic factors, including, neurotrophin-3 (NT-3) [67], neurotrophin-4/5 (NT-4/5) [68], brain-derived neurotrophic factor (BDNF) [69], glial cell linederived neurotrophic factor (GDNF) [70], and ciliary neurotrophic factor (CNTF) [71]. BDNF promotes the survival of existing neurons as well as the growth and differentiation of new neurons and synapses. BDNF and NT-3 activate tropomyosin-related kinase (Trk) receptor signaling pathways, which tends to increase axonal sprouting while also providing neuroprotective effects. Endogenous levels of NT-3 and BDNF are typically low in healthy spinal cord tissue; however, the expression of Trk receptor proteins increases in both neuronal and non-neuronal cells following injury. NTs play important roles in many facets of nerve regeneration following traumatic CNS injury. NT treatments promote neuronal survival, enhance the regrowth and remyelination of axons, and increase synaptic plasticity. GDNF is a potent neurotrophic factor that provides neuroprotective effects and increases axonal regeneration, plasticity, and remyelination [72]. Preclinical models of SCI have demonstrated that neurotrophic factors are instrumental in the post-injury remodeling of spinal cord circuitry $[19,63,64]$.

\section{Guided Axonal Regeneration}

Functional recovery depends on the successful regeneration of nerve fibers and their reconnection to target cells [73,74]. A neuron comprises a cell body (or soma), dendrites, and an axon. The dendrites receive signals, which are then passed through the cell body and out the end of the axon. During neuronal growth, when the proximal end of the axon reaches the distal end, the growth cone at the proximal end enters the neurodegenerative region, and demyelinated Schwann cells form endoneurial tubes with the surrounding basal lamina. The extracellular matrix subsequently interacts with some of the factors secreted by the neuron, thereby allowing the axon to reach its destination and complete nerve cell regeneration. However, defects in bridging due to glial scarring and post-traumatic cavitation associated with traumatic SCI can limit axonal regeneration and the functionality of synapses $[75,76]$. Thus, neurological recovery may require a graft to bridge a cavity, which acts to reduce neural tension and guide the regeneration of axons.

Implantable nanofabricated polymers are biodegradable and bioabsorbable and have demonstrated considerable promise in transplant surgery $[25,77]$. These non-toxic materials can be used to form robust bridges and scaffolds which facilitate nerve regeneration. Recent studies have also found that multiple poly (lactic-co-glycolic) channels can serve as bridges that physically direct the growth of axons across the injury while also optimizing the post-traumatic spinal cord microenvironment [78-80]. Numerous methods have been developed to synthesize bridges using natural or synthetic polymers [81], and certain biomaterials have been shown to provide neuroprotective benefits for SCI patients. For example, an investigation into the cotransplantation of QL6-SAP with neural stem/progenitor cells, Iwasaki et al. [82], the observed the preservation of motor neurons as well as the attenuation of perilesional inflammation. Other studies have reported remodeling the extracellular matrix using nanofibers, which serve as a scaffold and inhibit the formation of glial scars while facilitating the regeneration of axons $[81,83]$. Implanting nanofabricated polymers in multiple channels can help to overcome barriers to regeneration, provide physical axon guidance, prevent the formation of cavities, and protect regenerated neurons.

\begin{tabular}{|c|c|c|c|}
\hline Authors & Biomaterial scaffolds & Stem cells & Functions and improvements \\
\hline Xiao $Z$ et al. [92]. & $\begin{array}{l}\text { collagen (NeuroRegen) } \\
\text { scaffold }\end{array}$ & $\begin{array}{c}\text { autologous bone marrow } \\
\text { mononuclear cells }\end{array}$ & $\begin{array}{l}\text { Partially autonomic nervous function improvement, and the recovery of } \\
\text { somatosensory evoked potentials (SSEP) from the lower limbs was also detected. }\end{array}$ \\
\hline Zhao $Y$ et al. [93]. & $\begin{array}{l}\text { collagen (NeuroRegen) } \\
\text { scaffold }\end{array}$ & $\begin{array}{l}\text { human umbilical cord } \\
\text { mesenchymal stem cells }\end{array}$ & $\begin{array}{l}\text { Increased finger activity, enhanced trunk stability, defecation sensation, and } \\
\text { autonomic neural function recovery, were observed in some patients. }\end{array}$ \\
\hline Theodore $\mathrm{N}$ et al. [94]. & Neuro-Spinal ScaffoldTM & - & $\begin{array}{c}\text { By } 6 \text { months, } 3 \text { of } 5 \text { patients had converted from Abbreviated Injury Scale (AIS) A to } \\
\text { AIS B(2) or C(1). One patient gained } 10 \text { points of hip and knee function by } 6 \text { months, } \\
\text { with additional improvement and new ankle function at } 12 \text { months (increased motor } \\
\text { score of } 8 \text { ). One patient converted from AIS A to B at } 6 \text { months, a late-occurring } \\
\text { conversion that is extremely rare. }\end{array}$ \\
\hline Theodore N et al. [94] & Neuro-Spinal ScaffoldTM & - & $\begin{array}{l}\text { By } 3 \text { months, his neurological examination improved to an L1 AIS grade C } \\
\text { incomplete injury. At } 6 \text {-month postoperative follow-up, there were no procedural } \\
\text { complications or apparent safety issues related to the scaffold implantation. }\end{array}$ \\
\hline
\end{tabular}

Table 1: The current clinical applications of biomaterial scaffolds in $\mathrm{SCl}$ patients 


\section{Discussion}

The application of biomaterial scaffolds in multiple channels has been shown to promote long-term axon growth, enhance the myelination of neurons, and inhibit scar formation. However, it should be considered the influence of enhancement factors that had been incorporated into implantable nanofabricated polymers, such as extracellular matrix, growth and neurotrophic factors, as well as other materials capable of modulating remyelination, axonal regeneration, and neurological recovery [84-92]. Bio-absorbable materials have an advantage in the covering of cofactors; these are released by degradation and have a controlled release effect [79]. For example, lentiviral vectors encoding Lingo- 1 have been shown to negatively regulate myelination, and shRNA has been shown to promote functional recovery and nerve regeneration in cases of SCI [85]. Modified collagen hydrogels containing FGF-2 (bFGF) have also been shown to decrease the number of infiltrating astrocytes and promote neural regeneration in the treatment of SCI [86]. Thus, future research that investigates the use of biomaterial scaffolds in conjunction with cofactors should help improve the efficacy of SCI therapy.

The spinal cord contains myelin-sheathed neuronal tracts (including motor and sensory tracts), encased in white matter, which are responsible for afferent and efferent pathways [87,93]. These tracts guide nerve sprouting and stimulate the formation of nerve bundles, which may in-turn benefit axonal regeneration [88]. It was discovered that the use of multiple channel bridges in the treatment of SCI can direct the growth of neural fibers and facilitate spinal cord regeneration. In a similar study, plasmid-loaded multiple channel bridges were engineered to induce the growth of axons across the injury site $[89,94]$. Tuinstra et al. further established a multichannel bridge coating which was capable of delivering neurotrophin encoding lentiviruses to promote axonal regeneration following SCI [90]. Ideally, artificial tissue engineering techniques are meant to coat neural multichannel bridges with Schwann cells and macrophages, growth factors and neurotrophic factors, and an extracellular matrix in order to stimulate axonal growth and movement $[54,64,91]$. In summary, researchers should seek to improve the efficacy of SCI treatment, combined with the simultaneous transplantation of stem cells, by developing techniques which guide the regrowth of nerve cells.

\section{References}

1. Zhang F, Ru N, Shang ZH, Chen JF, Yan C, et al. (2017) Daidzein ameliorates spinal cord ischemia/reperfusion injury-induced neurological function deficits in Sprague-Dawley rats through PI3K/Akt signaling pathway. Exp Ther Med 14: $4878-86$

2. Osterholm JL, Mathews GJ (1972) Altered norepinephrine metabolism following experimental spinal cord injury: Part 1: Relationship to hemorrhagic necrosis and post-wounding neurological deficits. J Neurosurg 36: 386-394.

3. Lin CSY, Macefield VG, Elam M, Gunnar WB, Engel Set, et al. Axonal changes in spinal cord injured patients distal to the site of injury. Brain 130: 985-94.

4. (2016) Stem cells: Targeting pain of spinal-cord injury. Nature 537: 588.

5. Barde $Y(2009)$ Caution urged in trial of stem cells to treat spinal-cord injury. Nature 458: 29.

6. Nandoe TRS, Hurtado A, Bartels RH, Grotenhuis A, Oudega M (2009) Stem cell-based therapies for spinal cord injury. J Spinal Cord Med 32: 105-14.

7. Khan S, Mafi P, Mafi R, Khan W (2017) A systematic review of mesenchymal stem cells in spinal cord injury, intervertebral disc repair and spinal fusion. Curr Stem Cell Res Ther.

8. Chan TM, Chen JYR, Ho LI, Lin HP, Hsueh KW, et al. (2014) ADSC therapy in neurodegenerative disorders. Cell Transplant 23: 549-57.

9. Yeh DC, Chan TM, Harn HJ, Chiou TW, Chen HS, et al. (2015) Adipose tissuederived stem cells in neural regenerative medicine. Cell Transplant 24: 487-92.
10. Wu SH, Huang SH, Lo YC, Chai CY, Lee SS, et al. (2015) Autologous adiposederived stem cells attenuate muscular atrophy and protect spinal cord ventral horn motor neurons in an animal model of burn injury. Cytotherapy 17: 1066-75

11. All AH, Bazley FA, Gupta S, Pashai N, Hu C, et al. (2012) Human embryonic stem cell-derived oligodendrocyte progenitors aid in functional recovery of sensory pathways following contusive spinal cord injury. PLoS One 7: e47645.

12. Alizadeh A, Karimi AS (2016) Microenvironmental regulation of oligodendrocyte replacement and remyelination in spinal cord injury. J Physiol. 594: 3539-52.

13. Zahir T, Nomura H, Guo XD, Kim H, Tator C, et al. (2008) Bioengineering neura stem/progenitor cell-coated tubes for spinal cord injury repair. Cell Transplant 17: $245-254$

14. Cooper RA (2004) Bioengineering and spinal cord injury: a perspective on the state of the science. J Spinal Cord Med. 27: 351-364.

15. Wilcox JT, Cadotte D, Fehlings MG (2012) Spinal cord clinical trials and the role for bioengineering. Neurosci Lett 519: 93-102.

16. Samaddar S, Vazquez K, Ponkia D, Toruno P, Sahbani K, et al. (2017) Transspinal direct current stimulation modulates migration and proliferation of adult newly born spinal cells in mice. J Appl Physiol. 122: 339-353.

17. Kanno H, Pressman Y, Moody A, Berg R, Muir EM, et al. (2014) Combination of engineered Schwann cell grafts to secrete neurotrophin and chondroitinase promotes axonal regeneration and locomotion after spinal cord injury. $J$ Neurosci 34: 1838-1855.

18. Yu F, Morshead CM (2011) Adult stem cells and bioengineering strategies for the treatment of cerebral ischemic stroke. Curr Stem Cell Res Ther 6: 190-207.

19. Keefe KM, Sheikh IS, Smith GM (2017) Targeting Neurotrophins to Specific Populations of Neurons: NGF, BDNF, and NT-3 and Their Relevance for Treatment of Spinal Cord Injury. Int J Mol Sci. 18: 548.

20. Krautstrunk M, Scholtes F, Martin D, Schoenen J, Schmitt A, et al. (2002) Increased expression of the putative axon growth-repulsive extracellular matrix molecule, keratan sulphate proteoglycan, following traumatic injury of the adult rat spinal cord. Acta Neuropathol. 104: 592-600.

21. Shrestha B, Coykendall K, Li Y, Moon A, Priyadarshani P,et al. (2014) Repair of injured spinal cord using biomaterial scaffolds and stem cells. Stem Cell Res Ther 5: 91.

22. Kim M, Park SR, Choi BH (2014) Biomaterial scaffolds used for the regeneration of spinal cord injury (SCI). Histol Histopathol. 29: 1395-1408.

23. Saracino GA, Cigognini D, Silva D, Caprini A, Gelain F (2013) Nanomaterials design and tests for neural tissue engineering. Chem Soc Rev. 42: 225-262.

24. Straley KS, Foo CW, Heilshorn SC (2010) Biomaterial design strategies for the treatment of spinal cord injuries. J Neurotrauma. 27: 1-19.

25. Li X, Dai J (2017) Bridging the gap with functional collagen scaffolds: tuning endogenous neural stem cells for severe spinal cord injury repair. Biomater Sci.

26. Hosseini SM, Sharafkhah A, Koohi HO, Semsar KM (2016) Transplantation of Neural Stem Cells Cultured in Alginate Scaffold for Spinal Cord Injury in Rats. Asian Spine J. 10: 611-618

27. Wen Y, Yu S, Wu Y, Ju R, Wang HY, et al. (2016) Spinal cord injury repair by implantation of structured hyaluronic acid scaffold with PLGA microspheres in the rat. Cell Tissue Res. 364: 17-28.

28. Deng QY, Li SR, Cai WQ, Su BY (2006) Poly-lactic acid and agarose gelatin play an active role in the recovery of spinal cord injury. Neurosci Bull. 22: 73-8.

29. Yang Z, Zhang A, Duan H, Zhang S, Hao P, et al. (2015) NT3-chitosan elicits robust endogenous neurogenesis to enable functional recovery after spinal cord injury. Proc Natl Acad Sci. 112: 13354-59

30. Liu J, Chen Q, Zhang Z, Zheng Y, Sun X, et al. (2013) Fibrin scaffolds containing ectomesenchymal stem cells enhance behavioral and histological improvement in a rat model of spinal cord injury. Cells Tissues Organs. 198: 35-46.

31. Caicco MJ, Zahir T, Mothe AJ, Ballios BG, Kihm A, et al. (2013) Characterization of hyaluronan-methylcellulose hydrogels for cell delivery to the injured spinal cord. J Biomed Mater Res Part A. 101: 1472-1477.

32. Novikova LN, Novikov LN, Kellerth JO (2003) Biopolymers and biodegradable smart implants for tissue regeneration after spinal cord injury. Curr Opin Neurol. 16: 711-715. 
33. Guo JS, Qian CH, Ling EA, Zeng YS (2014) Nanofiber scaffolds for treatment of spinal cord injury. Curr Med Chem. 21: 4282-4289.

34. Macaya D, Spector M (2012) Injectable hydrogel materials for spinal cord regeneration: a review. Biomed Mater. 7: 012001.

35. Madigan NN, McMahon S, O’Brien T, Yaszemski MJ, Windebank AJ (2009) Current tissue engineering and novel therapeutic approaches to axonal regeneration following spinal cord injury using polymer scaffolds. Respir Physiol Neurobiol. 169: 183-199.

36. Pires LR, Pego AP (2015) Bridging the lesion-engineering a permissive substrate for nerve regeneration. Regen Biomater. 2: 203-214.

37. Montgomery A, Wong A, Gabers N, Willerth SM (2015) Engineering personalized neural tissue by combining induced pluripotent stem cells with fibrin scaffolds. Biomater Sci. 3: 401-413.

38. Tabesh H, Amoabediny GH, Nik NS, Heydari M, Yosefifard M, et al. (2009) The role of biodegradable engineered scaffolds seeded with Schwann cells for spinal cord regeneration. Neurochem Int. 54: 73-83.

39. Agbay A, Edgar JM, Robinson M, Styan T, Wilson K, et al. (2016) Biomaterial Strategies for Delivering Stem Cells as a Treatment for Spinal Cord Injury. Cells Tissues Organs. 202: 42-51.

40. Anderson MA, Burda JE, Ren Y, Ao Y, O'Shea TM, et al. (2016) Astrocyte scar formation aids central nervous system axon regeneration. Nature. 532: 195-200.

41. Kanno H, Pearse DD, Ozawa H, Itoi E, Bunge MB (2015) Schwann cell transplantation for spinal cord injury repair: its significant therapeutic potential and prospectus. Rev Neurosci. 26: 121-128.

42. Liu C, Huang $Y$, Pang M, Yang $Y$, Li S, et al. (2015) Tissue-engineered regeneration of completely transected spinal cord using induced neural stem cells and gelatin-electrospun poly (lactide-co-glycolide)/polyethylene glycol scaffolds. PLoS One. 10: e0117709.

43. Johansson CB, Momma S, Clarke DL, Risling M, Lendahl U, et al. (1999) Identification of a neural stem cell in the adult mammalian central nervous system. Cell. 96: 25-34.

44. Tuszynski MH, Wang Y, Graham L, Gao M, Wu D, et al. (2014) Neural stem cell dissemination after grafting to CNS injury sites. Cell. 156: 388-89.

45. Lu P, Wang Y, Graham L, McHale K, Gao M, et al. (2012) Long-distance growth and connectivity of neural stem cells after severe spinal cord injury. Cell. 150: 1264-73.

46. Hwang WS (2005) Patient-specific embryonic stem cells derived from human SCNT blastocysts. Science. 308: 1777-83

47. Iwai H, Shimada H, Nishimura S, Kobayashi Y, Itakura G, et al. (2015) Allogeneic Neural Stem/Progenitor Cells Derived From Embryonic Stem Cells Promote Functional Recovery After Transplantation Into Injured Spinal Cord of Nonhuman Primates. Stem Cells Transl Med. 4: 708-719.

48. Perry C, Mackay SA, Feron F, McGrath J (2002) Olfactory neural cells: an untapped diagnostic and therapeutic resource. Laryngoscope. 112: 603-07.

49. Joosten EA, Veldhuis WB, Hamers FP (2004) Collagen containing neonatal astrocytes stimulates regrowth of injured fibers and promotes modest locomotor recovery after spinal cord injury. J Neurosci Res. 77: 127-42.

50. Yang L, Ge Y, Tang J, Yuan J, Ge D, et al. (2015) Schwann Cells Transplantation Improves Locomotor Recovery in Rat Models with Spinal Cord Injury: a Systematic Review and Meta-Analysis. Cell Physiol Biochem. 37: 2171-82.

51. Oudega M, Xu XM (2006) Schwann cell transplantation for repair of the adult spinal cord. J Neurotrauma. 23: 453-67.

52. Yang EZ, Zhang GW, Xu JG, Chen S, Wang H, et al. (2017) Multichanne polymer scaffold seeded with activated Schwann cells and bone mesenchymal stem cells improves axonal regeneration and functional recovery after rat spinal cord injury. Acta Pharmacol Sin. 38: 623-37.

53. Burnside ER, Bradbury EJ (2014) Manipulating the extracellular matrix and its role in brain and spinal cord plasticity and repair. Neuropathol Appl Neurobiol 40: $26-59$.

54. Haggerty AE, Marlow MM, Oudega M (2017) Extracellular matrix components as therapeutics for spinal cord injury. Neurosci Lett. 652: 50-5.

55. Deng WP, Yang CC, Yang LY, Chen CWD, Chen, et al. (2014) Extracellular matrix-regulated neural differentiation of human multipotent marrow progenitor cells enhances functional recovery after spinal cord injury. Spine J. 14: 2488-99.
56. Chan TM, Lin HP, Lin SZ (2014) In situ altering of the extracellular matrix to direct the programming of endogenous stem cells. Stem Cells. 32: 1989-90.

57. Gaudet AD, Popovich PG (2014) Extracellular matrix regulation of inflammation in the healthy and injured spinal cord. Exp Neurol. 258: 24-34.

58. Chiu SC, Hung HS, Lin SZ, Chiang E, Liu DD (2009) Therapeutic potential of olfactory ensheathing cells in neurodegenerative diseases. J Mol Med. 87 1179-89.

59. Tukmachev D, Forostyak S, Koci Z, Zaviskova K, Vackova I, et al. (2016) Injectable Extracellular Matrix Hydrogels as Scaffolds for Spinal Cord Injury Repair. Tissue Eng Part A. 22: 306-17.

60. Zurita M, Otero L, Aguayo C, Bonilla C, Ferreira E, et al. (2010) Cell therapy for spinal cord repair: optimization of biologic scaffolds for survival and neura differentiation of human bone marrow stromal cells. Cytotherapy. 12: 522-37.

61. Kisseleva T, Brenner DA (2012) The phenotypic fate and functional role for bone marrow-derived stem cells in liver fibrosis. J Hepatol. 56: 965-972.

62. Ang XM, Lee MH, Blocki A, Chen C, Ong LS, et al. (2013) Macromolecular Crowding Amplifies Adipogenesis of Human Bone Marrow-Derived Mesenchymal Stem Cells by Enhancing the Pro-Adipogenic Microenvironment. Tissue Eng Part A. 20: 966-981.

63. Kelamangalath L, Smith GM (2013) Neurotrophin treatment to promote regeneration after traumatic CNS injury. Front Biol. 8: 486-495.

64. Hodgetts SI, Harvey AR (2017) Neurotrophic Factors Used to Treat Spinal Cord Injury. Vitam Horm. 104: 405-457.

65. Lu P, Jones LL, Snyder EY, Tuszynski MH (2003) Neural stem cells constitutively secrete neurotrophic factors and promote extensive host axonal growth after spinal cord injury. Exp Neurol. 181: 115-129.

66. Boyce VS, Mendell LM (2014) Neurotrophic factors in spinal cord injury. Handb Exp Pharmacol. 220: 443-460.

67. Elliott DI, Tator $\mathrm{CH}$, Shoichet MS (2016) Local Delivery of Neurotrophin-3 and Anti-NogoA Promotes Repair After Spinal Cord Injury. Tissue Eng Part A. 22 733-741.

68. Friedman B, Kleinfeld D, Ip NY, Verge VM, Moulton R, et al. (1995) BDNF and NT-4/5 exert neurotrophic influences on injured adult spinal motor neurons. $J$ Neurosci. 15: 1044-1056

69. Uchida S, Hayakawa K, Ogata T, Tanaka S, Kataoka K, et al. (2016) Treatment of spinal cord injury by an advanced cell transplantation technology using brainderived neurotrophic factor-transfected mesenchymal stem cell spheroids. Biomaterials. 109: 1-11.

70. Liu G, Wang X, Shao G, Liu Q (2014) Genetically modified Schwann cells producing glial cell line-derived neurotrophic factor inhibit neuronal apoptosis in rat spinal cord injury. Mol Med Rep. 9: 1305-1312.

71. Abbaszadeh HA, Tiraihi T, Noori-Zadeh A, Delshad AR, Sadeghizade, et al. (2015) Human ciliary neurotrophic factor-overexpressing stable bone marrow stromal cells in the treatment of a rat model of traumatic spinal cord injury. Cytotherapy. 17: 912-921.

72. Weishaupt N, Blesch A, Fouad K (2012) BDNF: the career of a multifaceted neurotrophin in spinal cord injury. Exp Neurol. 238: 254-264.

73. Owens J (2009) Stem-cell treatments for spinal-cord injury may be worth the risk. Nature. 458: 1101

74. Holmes D (2017) Spinal-cord injury: spurring regrowth. Nature. 552: S49.

75. Amr SM, Gouda A, Koptan WT, Galal AA, Abdel-Fattah, et al. (2014) Bridging defects in chronic spinal cord injury using peripheral nerve grafts combined with a chitosan-laminin scaffold and enhancing regeneration through them by co-transplantation with bone-marrow-derived mesenchymal stem cells: case series of 14 patients. J Spinal Cord Med. 37: 54-71.

76. Brazda N, Estrada V, Voss C, Seide K, Trieu HK, et al. (2016) Experimental Strategies to Bridge Large Tissue Gaps in the Injured Spinal Cord after Acute and Chronic Lesion. J Vis Exp. e53331.

77. Sakiyama-Elbert S, Johnson PJ, Hodgetts SI, Plant GW, Harvey AR (2012) Scaffolds to promote spinal cord regeneration. Handb Clin Neurol. 109: 575-94.

78. Tuinstra HM, Margul DJ, Goodman AG, Boehler RM, Holland SJ, et al. (2014) Long-term characterization of axon regeneration and matrix changes using multiple channel bridges for spinal cord regeneration. Tissue Eng Part A. 20: 1027-37. 
Citation: Yeh DC (2018) Holistic Approach to Axonal Regeneration in Cases of Spinal Cord Injury. J Biomol Res Ther 7: 158. doi:10.4172/2167-7956.1000158

79. Slotkin JR, Pritchard CD, Luque B, Ye J, Layer RT, et al. (2017) Biodegradable scaffolds promote tissue remodeling and functional improvement in non-human primates with acute spinal cord injury. Biomaterials 123: 63-76.

80. Ropper AE, Thakor DK, Han I, Yu D, Zeng X, et al. (2017) Defining recovery neurobiology of injured spinal cord by synthetic matrix-assisted hMSC implantation. Proc Natl Acad Sci 114: E820-E829.

81. Tysseling-Mattiace VM, Sahni V, Niece KL, Birch D, Czeisler C, et al. (2008) Self-assembling nanofibers inhibit glial scar formation and promote axon elongation after spinal cord injury. J Neurosci 28: 3814-3823.

82. Iwasaki M, Wilcox JT, Nishimura Y, Zweckberger K, Suzuki H, et al. (2013) Synergistic effects of self-assembling peptide and neural stem/progenitor cells to promote tissue repair and forelimb functional recovery in cervical spinal cord injury. Biomaterials 35: 2617-2629.

83. Khaing ZZ, Milman BD, Vanscoy JE, Seidlits SK, Grill RJ, et al. (2011) High molecular weight hyaluronic acid limits astrocyte activation and scar formation after spinal cord injury. J Neural Eng 8: 046033.

84. Karimi-Abdolrezaee S, Eftekharpour E, Wang J, Morshead CM, Fehlings MG (2006) Delayed transplantation of adult neural precursor cells promotes remyelination and functional neurological recovery after spinal cord injury. $J$ Neurosci 26: 3377-3389.

85. Wu HF, Cen JS, Zhong Q, Chen L, Wang J, et al. (2013) The promotion of functional recovery and nerve regeneration after spinal cord injury by lentiviral vectors encoding Lingo-1 shRNA delivered by Pluronic F-127. Biomaterials 34 : 1686-1700.

86. Shi Q, Gao W, Han X, Zhu X, Sun J, et al. (2014) Collagen scaffolds modified with collagen-binding bFGF promotes the neural regeneration in a rat hemisected spinal cord injury model. Sci China Life Sci 57: 232-240.
87. Huang JH, Cullen DK., Browne KD, Groff R, Zhang J, et al. (2009) Long-term survival and integration of transplanted engineered nervous tissue constructs promotes peripheral nerve regeneration. Tissue Eng Part A 15: 1677-1685.

88. Yang Y, Laporte LD, Zelivyanskaya ML, Whittlesey KJ, Anderson AJ, et al (2009) Multiple channel bridges for spinal cord injury: cellular characterization of host response. Tissue Eng Part A 15: 3283-3295.

89. De Laporte L, Yang Y, Zelivyanskaya ML, Cummings BJ, Anderson AJ, et al (2009) Plasmid releasing multiple channel bridges for transgene expression after spinal cord injury. Mol Ther 17: 318-326.

90. Tuinstra HM, Aviles MO, Shin S, Holland SJ, Zelivyanskaya ML, et al. (2012) Multifunctional, multichannel bridges that deliver neurotrophin encoding lentivirus for regeneration following spinal cord injury. Biomaterials 33: 16181626.

91. Song Z, Wang Z, Shen J, Xu S, Hu Z (2017) Nerve growth factor delivery by ultrasound-mediated nanobubble destruction as a treatment for acute spinal cord injury in rats. Int J Nanomedicine 12: 1717-1729.

92. Xiao Z, Tang F, Tang J, Yang H, Zhao Y, et al. (2016) One-year clinical study of NeuroRegen scaffold implantation following scar resection in complete chronic spinal cord injury patients. Sci China Life Sci 59: 647-655.

93. Zhao Y, Tang F, Xiao Z, Han G, Wang N, et al. (2017) Clinical Study of NeuroRegen Scaffold Combined With Human Mesenchymal Stem Cells for the Repair of Chronic Complete Spinal Cord Injury. Cell Transplant 26: 891-900.

94. Theodore N, Kim KD, Hsieh PC, Ray WZ, Barry M, et al. (2016) 178 High Abbreviated Injury Scale Grade Conversion Rate Following Neuro-Spina Scaffold Implantation in Acute Thoracic Complete Abbreviated Injury Scale A Spinal Cord Injury: Potential Mechanisms. Neurosurgery 63 (Suppl 1): 171. 